\title{
INTER-LANGUAGE COMPARISON \\ OF THE FORMS OF CONCEPT SEMIOTIZATION \\ IN THE TRANSLATION ASPECT
}

\section{Soroka T. V.}

\section{INTRODUCTION}

At the turn of the millennium, linguistics increasingly poses the question of the need to raise cross-language comparative research to a qualitatively new level in the description and explanation of linguistic facts based on the study of their national and cultural specifics through the prism of language consciousness (its ethno-cultural specifics) and linguistic and cultural competence ${ }^{1}$. This research position, of course, requires the use of methods aimed at analyzing the conceptual and symbolic consolidation of not only the relations between objects and phenomena of the objective world, but also the relations of a person to this world, focusing on the cultural factor in language and the language factor in a person ${ }^{2}$.

Language as a mirror, according to S.G. Ter-Minasova, reflects both worlds: an outside world surrounds a person and an inside world created by a person. At the same time, the mirror of language reflects the person oneself, one's way of life, behavior, system of values, culture - the world inside a person. It is very interesting to study one worldview against the background of another, fixed in the language ${ }^{3}$.

\section{The problem's prerequisites emergence and the problem's formulation}

The relevance of this study is due to the general orientation of modern linguistics towards the integration of cross-linguistic comparative and linguoculturological approaches, the need for a more detailed study of the concepts of one culture against the background of

1 Durand G. Les structures anthropologiques de l'imaginaire. Paris : Dunod, 1997. $536 \mathrm{p}$.

${ }^{2}$ Маслова В.А. Лингвокультурология. Москва : Академия, 2001. С. 8.

3 Тер-Минасова С.Г. Язык и межкультурная коммуникация. Москва : Слово, 2000. C. 259. 
other ethno-cultural linguistic traditions in order to identify common culturally-typical and nationally-specific conceptual components in their verbal and semantic manifestations.

In the scientific researches of linguists (works of Yu.D. Apresyan, N.D. Arutyunova, A. Vezhbitskaya, L.P. Ivanova, D.S. Likhachev, E.S. Kubryakova, E.A. Selivanova, Yu.S. Stepanov, V.N. Telia, A.D. Shmelev, etc.), concepts are interpreted as mental formations stored in the memory of a person in the form of certain "quanta" of knowledge, significant and typified fragments of practical experience. In foreign resources, the notion of a concept is correlated with the notion of a domain, a cognitive model, and a cognitive category (G. Lakoff).

The concept can be based on knowledge of different degrees of abstraction and formats: 1) concrete and sensual image (concrete phone); 2) representation (mental picture as a generalized sensual image, such as a phone at all); 3) scheme - a mental sample of an object or phenomenon having a spatially-contour character (geometric aspect of the submission, the general outlines of something, for example, a house, a human figure, mechanical trajectory); 4) notion - a concept containing the most common, essential attributes of an object or phenomenon, its objective, logical design features (notion is a concept devoid of secondary characteristics, from the standpoint of logical analysis); 5) prototype - a categorical concept, which gives an idea about a typical member of the definite category (a typical representation of a car or of a politician, etc., it is the rationale for the conceptualization, segregating something typical on the basis of experience); 6) propositional structure, or proposition - a model of a certain area of experience, in which elements (arguments and connections between them) are isolated, their characteristics are given; this is a generalized logical model of relations, reflected in deep grammar; 7) frame - a three-dimensional multicomponent concept that represents a "package" of information, knowledge about a stereotypical situation, a frame is a two-level structure consisting of vertex nodes that contain constant data for a certain situation, and terminal nodes, or slots, filled with data from a specific situation, for example, the "theatre" frame includes the vertex nodes "ticket office", "stage", "auditorium", "performance", etc., and terminal nodes, for example: "queue at the ticket office of a particular theater, impressions associated with this event in which I took part"; analyzing the second-level frames (nested frames, or subframes), we restore the situation as a whole; 8) scenarios, or scripts - dynamically presented frames, a sequence of stages, episodes unfolding in time (for example, a visit to the theater); 9) gestalt - a 
conceptual structure, a holistic image that combines sensory and rational components in their unity, as a result of an undifferentiated perception of the situation, the highest level of abstraction: non-discrete, unstructured knowledge.

At the same time, current studies do not give a complete definition of concept, since the meaning of this term is determined by the internal form of the word. The typicability of these units fixes representations in the form of various stereotypes, their awareness makes it possible to convey information about them to other people, their significance fixes important characteristics of reality in individual and collective experience. These characteristics of concepts are realized in their imaginative-perceptual, notional and symbolic forms of semiotization.

According to N.F. Alefirenko ${ }^{4}$, the imaginative embodiment of the concept is associated with the formation of the denotative macrocomponent of the semantic structure of the language sign, represented by the figurative meanings of the word (metaphorical, metonymic, etc.). The concept-image at the first stage is formed as a structure that includes direct, substantive-shaped forms of reflection of objects and actions with them. In this hypostasis, the concept is objectified in the semantic structure of the word in the form of a framework (G.G. Shpet). Then, on its basis, more abstract semantic layers of the concept will be formed, verbalized by linguistic signs of a direct-nominative and symbolic nature. The notional implementation of the concept is a cognitive basis for the formation of a significative macro-component of lexical meaning. The symbolic hypostasis of the concept serves as a cognitive basis for the development of the connotative macro-component in the structure of lexical meaning, which is directly related to the linguistic and cultural everyday consciousness of the people.

\section{The analysis of existing methods for solving the problem and formulating a task for the optimal technique development}

The purpose of this study is to provide a cross-cultural comparative analysis of the forms of semiotization of the concept family in the English and Russian linguistic communities, as a result of which it is supposed to reveal the degree of its perception by the linguistic consciousness of representatives of these ethnolinguocultures.

4 Алефиренко Н.Ф. Спорные проблемы семантики: Монография. Москва : Гнозис, 2005. С. 138-143. 
The material of the study was the microtexts of the novel by J. Galsworthy's "The Forsyte Saga" and their translations into Russian.

It should be noted that the article contains a subscript translation of the fragments of the novel with elements of syntactic assimilation in order not to re-express the meaning in an artistic way, but to maximize the preservation of the meanings of English words as material facts reflecting the worldview of the classic writer. The consideration of the same context in which a similar concept is implemented in the English microtext and its Russian translation made it possible to carry out a more thorough cross-language comparison and identify specific national conceptual features.

Since the concept is defined as a set of meanings that a person operates with in the process of thinking, structured in the form of images, pictures, frames and having a linguistic expression, it is advisable to start a conceptual analysis within the framework of poetic or prose literary works, since the concept, according to V.V. Kolesov ${ }^{5}$, is usually recreated by the trace left by it in classical exemplary texts. It follows that the most valuable observations can be made by studying its manifestations in the artistic speech of great writers, whose creative work is a living environment for the development of the concept.

The study of the concept in the text, according to L.G. Babenko ${ }^{6}$, involves taking into account, along with the paradigmatic ones, mainly syntagmatic connections of words, since the concept in a fiction novel is formed on a syntagmatic level, has an intra-textual syntagmatic nature. The process of conceptualization itself, carried out on the material of a literary text, has its own specifics, which is based on the semantic derivation of contextual components from a set of linguistic units that reveal one topic, a microteme. As a result, the conceptual space of the text is formed at a higher level of abstraction - on the basis of the merger, convergence, and aggregation of common features of concepts represented at the surface level of the text by words and sentences of one semantic domain, which also determines a certain integrity of the conceptual sphere of the text, and the key concept is the core of the individual author's artistic picture of the world, embodied in a separate work.

${ }^{5}$ Колесов В.В. О логике логоса в сфере ментальности. Мир русского слова. 2000. № 2. С. 56.

${ }^{6}$ Бабенко Л.Г. Лингвистический анализ художественного текста. Теория и практика. Москва : Флинта : Наука, 2005. С. 58. 
The constituent represents the lexeme family in two types of contextual representations: as part of two-component asyndetic noun phrases and as a syntactically-conditioned functional member of a sentence.

The deep structure of the two-component $\mathrm{N}+\mathrm{N}$ model reveals the striking differences in the compared languages. Attributive relations within the English construction $\mathrm{N}+\mathrm{N}$ are provided by the use of the noun-definition family (attributive noun) in the form of the common case in the preposition to the dominant word $\left(\mathrm{N}_{\text {atr. }}+\mathrm{N}\right)$. In Russian, the determinative relations are provided by the noun-definition in the genitive case, which stands in the postposition to the word being defined $\left(\mathrm{N}+\mathrm{N}_{\text {gen. }}\right)$.

The lexeme family is an element of the epithet construction created according to the model: $\mathrm{N}_{1}$ (the core component - family) $+\mathrm{N}_{2}$ (the dependent component). The dominant method of contextual interpretation of these constructions is the calque one. This is a special type of borrowing, when the structural and semantic models of the source language are recreated as element-by-element by the material means of the translating language. The analyzed English epithet constructions have clear syntactic features. However, according to V. Matesius ${ }^{7}$, since each language perceives reality in its own way, therefore, it forms it according to its own system and cultural tradition. Therefore, according to R.P. Zorivchak ${ }^{8}$, while calquing a simple replacement is not always possible, since numerous calqued statements differ in their structure in comparison with calqued objects and do not correspond to the category of literal copies.

Based on this, in this conceptual analysis, Russian calques are those epithet constructions that primarily preserve denotative and / or connotative content layers, for example: Among the younger generation... there was this same stamp - less meaningful perhaps, but unmistakable - a sign of something ineradicable in the family soul ${ }^{9}$. Все представители младшего поколения были отмечены этой же печатью, может быть, менее значимой, но безусловно очевидной и являющейся неким знаком чего-то неискоренимого в самой семейной душе.

${ }^{7}$ Матезиус В. Язык и стиль. Пражский лингвистический кружок. Москва : Прогресс, 1967. С. 445.

8 Зорівчак Р.П. Фразеологічна одиниця як перекладознавча категорія (На матеріалі перекладів творів української літератури англійською мовою). Львів : Вид-во при Львів. ун-ті, 1983. С. 89.

${ }^{9}$ Galsworthy J. The Forsyte Saga. Book One. The Man of Property. Moscow : Progress, 1974. P. 32. 
The dictionary definition proposes the following features of the used lexeme soul: Soul - the part of a person which some people believe is spiritual and continues to exist in some form after their body has died, or the part of a person which is not physical and experiences deep feelings and emotions ${ }^{10}$. - Душа - та часть человека, которая, по представлениям некоторых людей, возвышенна и продолжает существовать в некой форме после смерти, или нефизическая часть человека, выражающая глубокие чувства и эмоции.

The difference between the English lexeme soul and the Russian nomen душа consists in the ethnic stereotype of perception of these concepts: if the Englishman associates soul "with a religious notion, then in the mind of the Russian, душа is not so much of divine essence as human one. The Russian word is connected with the psychological processes taking place within a human being.

I.A. Golubovskaya, analyzing the variations in the use of these lexemes, the relations of which can be described as equipolent oppositions, emphasizes that both in Russian and Ukrainian cultures, the concept душа acts as the "alter ego" of a person, the main regulator of one's mental life, and above all emotional life ${ }^{11}$

The deep connection between the notion душа and a concrete person is also objectified in a significant massif of Russian phraseology (божья душа, простая душа, христианская душа, etc.). Like an alive person, душа радуется, болит, не принимает чего-либо. In the Russian language picture of the world, душа is perceived as a certain organ, for example, similar to the heart, which is located somewhere in the chest of a person and is responsible for one's inner life. Both words дyma and сердие can want and feel. In cases of mental or emotional discomfort, душа changes its place (душа в пятки ушла, душа не на месте). Душа acts as an indicator of the emotional and mental state. A marker of such states is a state of physical lightness or heaviness (камень на душе камень с души свалился, тяжело - легко на душе). According to the naive language consciousness, душа is a container, a receptacle (в глубине души, влезть в душу, заглядьвать в душу, вырывать из

${ }^{10}$ Cambridge International Dictionary of English. Cambridge : Cambridge University Press, 1995. P. 1549.

${ }^{11}$ Голубовська I.О. Етнічні особливості мовних картин світу : Монографія. Київ : Логос, 2004. Р. 98. 
души, плевать в душу, хранить в тайниках души) ${ }^{12}$. The analysis shows that the linguistic conceptualization of the lexemes soul and $\partial y m a$ is the result of a complex interweaving of different aspects of what is called ethnic mentality. And no matter how close these nomens may seem, they are likely to enter into a relationship of interlanguage hyponymy, rather than a complete semantic identity, especially if we are talking about the key concepts of two nationally-linguistic-cultural communities.

The high degree of abstraction that is inherent in the meaning of a word, its flexibility in lexical connections with other units of the language vocabulary is largely determined by motivational features ${ }^{13}$. This can be traced in this example: $<\ldots>$ the sound of family tongues buzzing in his ears $<\ldots>^{14}$ [Book One, 72] - <..> в ушах у него уже стояло жужжание семейных языков <...>.

The verb buzz, according to scientists ${ }^{1516}$, has a phoneticmorphological motivation of meaning, preserving the residual phenomenon of sound-hereditary character, according to the theory of the origin of languages, according to which language arose as a result of a person's capability to imitate sounds produced by living beings and inanimate objects ${ }^{17}$, and from sounds, according to I.G. Herder ${ }^{18}$, "turned by reason into signs, words arose". In the structure of the predicate buzz, there is a component (the doubled consonant $\mathrm{Z}$ in the base of the word) that conditionally imitates the buzzing of an insect (cf., for example, onomatopoeia in the Ukrainian word базікати). As a result, it becomes clear how vividly the metonymic transfer of family tongues buzzing (=human buzzing) explicates the degree of annoyance of the constant

12 Снитко Е.С. Этнические культуры в зеркале язика. Мова $i$ культура: Наукове видання. Київ : Вид. Дім Дмитра Бураго, 2003. Т. IV. Вип. 6: Міжкультурна комунікація. Теорія і практика перекладу. С. 9.

13 Мостовий М.І. Лексикологія англійської мови. Харків : Основа, 1993. С. 84.

${ }^{14}$ Galsworthy J. The Forsyte Saga. Book One. The Man of Property. Moscow : Progress, 1974. Р. 72.

${ }^{15}$ Арнольд И.В. Лексикология современного английского языка. Москва : Высш. шк., 1986. С 33.

16 Лексикология английского языка / Р.З. Гинзбург, С.С. Хидекель, Г.Ю. Князева, А.А. Санкин. М. : Высш. шк., 1979. С. 26.

17 Языкознание. Большой энциклопедический словарь. Москва : Больш. Рос. энцикл., 2000. С 165.

18 Зубкова Л.Г. Лингвистические учения конца XVIII - начала XX в.: Развитие общей теории языка в системных концепциях. Монография. Москва : Изд-во УДН, 1989. С 9. 
repetition addressed to the recipient. In the Russian language tradition, there is a similar phraseological expression жужжать на ухо, where the triple phonemic combination жж carries a more negative connotation of meaning with an element of irritation for the individual.

The English in the family, according to J. Gorer ${ }^{19}$, are characterized by their courtesy and sensitivity to the feelings of their relatives. For example $<\ldots>$ the deep craving he himself had for the protection of the family wing reacted in turn on his feelings towards his own children ${ }^{20}$ <..> острая потребность чувствовать над собой защиту семейного крыльишка влияла, в свою очередь, и на его отношение $к$ детям. The phraseological combination the family wing is equivalent to the Russian version под крылышиком in the meaning of "under the protection; under the care, under the supervision" with the only difference - the absence of a diminutive suffix in the English version. In the Russian culture, it is customary to perceive someone's guardianship as something sincerely given, protecting from various disasters. The image of под крыльишком with its soft and delicate plumage represents human kindness and care.

In other cases, the equivalent correspondences in the Russian interpretation are selected on the basis of another image that has similar connotations and contains an equivalent component of emotional influence on the recipient, for example: $\langle\ldots\rangle$ this resentment expressed itself in $\langle\ldots\rangle$ an exuberance of family cordiality ${ }^{21}-<\ldots>$ эmom протест выражался избытком родственного радушия. The English noun cordiality formed from the Latin basis of the word cord (=heart) ${ }^{22}$, is replaced by the Russian lexeme paдyшuе (from paда душа), which acts as a carrier of a certain ethical ideal, the external manifestation of which is expressed in affectionate treatment of people, friendliness and hospitality. The esoteric nature of cordiality objectifies own semantics of the word - "a feeling of love or friendship manifested in a strong attachment to someone", and in case of loss of such a relationship, a person has a mental, that is, a psychological crisis. Therefore, the specificity of the English ethical element expressed by cordiality and

${ }^{19}$ Gorer J. Exploring English Character. New York, Criterion Books, 1955. P. 287.

${ }^{20}$ Galsworthy J. The Forsyte Saga, Book One. The Man of Property. Moscow : Progress, 1974. P. 94.

${ }^{21}$ Ibid. P. 30.

${ }^{22}$ The New Oxford Dictionary of English. Oxford: Oxford University Press, 1998. P. 407. 
representing refraction of the cultural values of the family in the rules of good taste, differs from радушия in the depth of expressed feelings and emotional manifestations.

It is known that the British honour their traditions. The traditionalism of behavior is expressed in a significant number of rituals. The notions of etiquette and ritual coincide in the sense that both ones relate to a system of fixed forms of behavior, and represent regulated actions ${ }^{23}$, are opposed to purposeful action (natural behavior), since for ritual and etiquette, the form is more important than the goal. At the same time, ritual and etiquette are different in their essence. The main difference between these concepts is, according to A.K. Bayburin ${ }^{24}$, in the everyday nature of etiquette and the sacred nature of the ritual. Etiquette expresses the norm of everyday relations in the conditions of biosocial stratification of the collective. The ritual confirms the truth and validity of this stratification. Etiquette is variable, while ritual tends to the absolute reproduction of the form of a certain action. During the ritual, the essence of the status of people who perform something sacred changes (hence the ritual understanding of burial rites). For example: "Where are you going to put him? He ought to have a pyramid by rights". Soames shook his head. "Highgate, the family vault",25 - Гдe тыл думаешь его похоронить? Он заслужил пирамиду. Сомс покачал головой. - В Хайгете, в фамильном могильном склепе. In the Russian version, the attributive clarification фамильньй appears (in contrast to the literal definition of семейный), since it is associated with the name of a closed underground room - a burial vault, in which coffins are installed with the dead who are in close relations with each other.

The method used in the translation of the two above-mentioned epithet constructions with the lexeme family is a sence-imaginative calque (the term of R.P. Zorivchak). In the process of interpreting epithet imagery, the primary task was not to find lexical-grammatical and syntactic equivalents successfully, but to ensure functional and communicative adequacy of the translation, which is achieved by

23 Шрейдер Ю.А. Ритуальное поведение и формы косвенного целеполагания. Психологические механизмы регуляции социильного поведения. Москва : Наука, 1979. С. 103-127.

${ }^{24}$ Байбурин А.К. Об этнографическом изучении этикета. Этикет у народов Передней Азии. Москва : Наука (Глав. ред. вост. лит.), 1988. С. 18.

${ }^{25}$ Galsworthy J. The Forsyte Saga. Book Three. To Let. Moscow : Progress, 1975. P. 14. 
creating a imaginative-connotational level in the semantic structure of the concept phrase.

She's the skeleton in the family cupboard, isn't she $?^{26}-$ Она точно скелет в семейном шкафу, не так ли? (= "family secret; symbol of trouble hidden from outsiders" / expression introduced into literature by $\mathrm{W}$. Thackeray/). The attribute that makes up the imaginative component of the content of the nomen the skeleton is generally absent in the Russian consciousness on the basis on which it was created in the original. In this case, the equivalent reproduction of this element of the meaning of the lexeme is impossible even within the entire utterance, that is, by combining a number of other language signs - in the family cupboard, and in translation the image is lost.

Those $\langle\ldots\rangle$ have seen that charming and instructive sight - an upper-middle class family in full plumage ${ }^{27}$. - Тем <...> являлось очаровательное и поучительное зрелище: представленная во всем блеске семья, принадлежащая к верхушке английской буржуазии. The complex definition of an upper-middle is composed by combining two components, each of which forms a separate phraseological combination - the middle class and the upper class.

England is a state with a very developed social system, in which "the very idea of equality was surprising and even offensive to its citizens" 28 . David Kennedine ${ }^{29}$, assessing the state structure of England, argued that the British had always considered themselves to belong to an unequal society, which seemed to them as a shrouded one in a whole network of layered social gradations, formed under the influence of traditions and religion, and sanctified by time itself. They could be arranged in the form of a hierarchical ladder, starting from the monarch at the top and then descending to the bottom to the poorest class.

Taking into account all the above, we will reveal the meanings of the selected phraseological combinations that characterize the class composition of the population of English society at the turn of the century (XIX-XX centuries). The petty bourgeoisie, called the middle class, was very heterogeneous in composition and origin. These were small entrepreneurs who had up to five hired workers, the main part of

${ }^{26}$ Galsworthy J. The Forsyte Saga. Book Two. In Chancery. Moscow : Progress, 1975. P. 169.

${ }^{27}$ Ibid. P. 29.

28 Bedarida Francois A social history of England. London and New York, 1994. P. 98.

${ }^{29}$ Cannadine David History in our time. Penguin Books, 2000. P. 5. 
farmers, persons of free professions, many owners of small trading enterprises, etc. In the era of the industrial revolution and the development of capitalist relations within the country, the middle classes were replenished with specialists, engineers, scientists and other highlyqualified workers, whose number grew. The upper class consisted of a large bourgeoisie and landed aristocracy (landlords) with a noble title, occupying the top of the hierarchical ladder of the British society. Both economic levers and political power were concentrated in their hands. This estate was joined by the upper-middle class (representatives of the upper middle class without a noble title), consisting of managers and administrators of various enterprises, banks, as well as major specialists. These two upper estates (the upper class and the upper-middle class) characterized the life style of people determined by the dominant property, suggesting extended families-clans and the special power of senior family members (property managers) ${ }^{30}$.

As the analysis shows, the internal form of the secondary nomination signs is much more informative than the internal form of the verbal signs of the direct nomination, because, firstly, it projects in the semantics of phraseological combinations not only the features of elements of the denotative situation, but also the relations between them, and secondly, it refracts and concretizes the subjective meanings focused in it.

There he sat in the gloomy comfort of the room, a puppet in the power of great forces that cared nothing for family or class or creed ${ }^{31} .-$ Так он сидит, окруженный унылым комфортом, марионетка в руках великих сил, которые не знают снисхождения ни к семье, ни к классу, ни к верованиям. Among the above-listed true values in the life of the British (family, class, creed), the notion family occupies an initial and fundamental position in the structure of society, thereby emphasizing that a family in the English culture is a unit of society that obeys the laws, moral norms (beliefs, traditions) established both inside it and outside, that is, the class to which it belongs and functions in an indissoluble connection.

$<\ldots>$ evidence of that mysterious concrete tenacity which renders $\underline{a}$ family so formidable a unit of society, so clear a reproduction of society in miniature ${ }^{32}$. - <..> очевидность той загадочной, несокруиимой

${ }^{30}$ Cannadine David History in our time. Penguin Books, 2000. P. 5.

${ }^{31}$ Galsworthy J. The Forsyte Saga. Book One. The Man of Property. Moscow : Progress, 1974. P. 59.

${ }^{32}$ Ibid. P. 29. 
стойкости, которая изображает семью как важную часть общества, такое же точное воспроизведение общества в миниатюре. The microcontext confirms the fact that the family as a kind of community of people affects all aspects of social life; all social processes are directly or indirectly connected with it. At the same time, the family has a relative autonomy from socio-economic relations, acting as one of the most traditional and stable social institutions.

Margaret Thatcher, highlighting the most significant social norms and values of the British culture, instilled in every citizen of the country during the $\mathrm{XIX}^{\text {th }}$ and $\mathrm{XX}^{\text {th }}$ centuries, said that the process of socialization of the British had always begun in the family, and then continued in society. The representatives of her generation, for example, were taught to work hard, to assert themselves, to live on their income, and subsequent generations are brought up under the motto: to develop a sense of self-esteem, to help others, to be proud of their country ${ }^{33}$. The results and effectiveness of family upbringing in the context of social renewal of society were determined not so much by how it ensured the assimilation of cultural values and social experience by a person, but by the readiness of society members for conscious and independent creative activity, which allowed them to set and solve tasks that had no analogues in the experience of past generations.

"I've never known Uncle Nicholas other than "very poorly, $<\ldots>$ or seen him look other than everlasting. What a family! $!^{34}-$ "Не помню, чтобы когда-нибудь дядя Николас не жаловался, что он плохо себя чувствует, <..> и всегда он выглядит так, словно собирается жить вечно! Вот семья! Qualificative definitions of the relative pronoun what are not named, but are clearly deciphered by the participants of the communicative act on the basis of the phenomenon of semantic inclusion, which, according to V.A. Kukharenko ${ }^{35}$, means such an enrichment of the meaning of one word at the expense of another word constantly or often adjacent to it. This latter is excluded from speech, completely dissolving into the first, being included in it. The phrase Вот семья! suggests filling its empty semantic capacity with

${ }^{33}$ Himmelfarb, Gertrude The De-Moralisation of Society From Victorian Virtues to Modern Values. N.Y. : Alfred A. Knopf, 1985. P. 4.

${ }^{34}$ Galsworthy J. The Forsyte Saga. Book One. The Man of Property. Moscow : Progress, 1974. P. 83.

${ }^{35}$ Кухаренко В.А. Интерпретация текста. Москва : Просвещение, 1988. С. 35. 
contextual meaning - Вот долгожители!, that is, implicitly states the hereditary trait of the appearance of relatives.

The content of the analysed concept covers various aspects of expression: from direct correlation with the kinship unity семьей/семейством to the characteristic of the word дома in its metonymic expression, for example: $<\ldots>$ he loved the family hearth... ${ }^{36}$ - <...> он любил семейный очаг. Both in the English and Russian cultures, the house is often referred to as a hearth (oyaz), thus emphasizing its traditional purpose to warm people's hearts. A family home becomes a hearth if its members have the opportunity and strive to meet their needs for support and emotional security, in high-quality interpersonal relationships, in identification with family values, that is, when a family home becomes a refuge for a person, in which one can always hide from everyday troubles, get advice, and where one is certainly recognized and loved.

Aunt Ann's eyes rested on him proudly; the eldest of the nephews since young Jolyon's departure from the family nest ${ }^{37}$ - Глаза тети Энн покоились на нем с гордостью: этот племянник, самый старший с тех пор, как молодой Джолион покинул семейное гнездо. When identifying the same denotation (nеst - гнездо), a complete crosslanguage equivalence is found. Historically, the family hearth in two ethnic cultures is sometimes metaphorically called as a nest. Etymological interpretations of the two lexemes reveal similar semantic features of nest and гнездо.

If we turn to the definitions that characterize the analyzed denotations and are essentially synonymous, we find some distinctive points. The English phrase the family nest, compared with the Russian семейное/родное гнездо, is associated with the place of residence of people who are related by blood in a direct line. However, the equivalent attribute родное appears emotionally higher in its semantics, implying, in addition to the above purpose, also the place of birth of a person, which has become one's small homeland.

We've never had a divorce in the family ${ }^{38}-Y$ нас в семье никогда не было разводов. The microcontext confirms that in the English rich

${ }^{36}$ Galsworthy J. The Forsyte Saga. Book One. The Man of Property. Moscow : Progress, 1974. P. 93.

${ }^{37}$ Ibid. P. 41.

${ }^{38}$ Galsworthy J. The Forsyte Saga. Book Two. In Chancery. Moscow : Progress, 1975. P. 43. 
dynasties of the XIX century, marriages were performed not only by mutual choice of the spouses, but were primarily symbolic incorporation into a large family as a clan.

\section{CONCLUSIONS}

Thus, in the course of cross-cultural comparative analysis of forms of semiotization of the concept family in the English and Russian linguistic communities on the material of John Galsworthy's novel "The Forsyte Saga" and translation of its microtexts into Russian. The concept family is recognized as the main unit of linguo-culturology and is considered as a multidimensional culturally-significant socio-psychic formation in the collective consciousness, defined in one or another language form. It has been found that this concept, being a multi-layered mental formation includes imaginative-perceptual, notional and symbolic components in its structure. In the semantic structure of the word the concept family projects a wide range of its sence content of an extensional and intensional nature. The prospect of research is to study in the translation aspect the semantic content of the inter-conceptual associative connections of the key lexeme family (the core of the concept) with other concepts that build cause-and-effect hierarchical subordinations and form a single conceptual sphere of intra-family relations of people.

\section{SUMMARY}

The article is dedicated to the cross-cultural contrastive analysis of imaginative-perceptual, notional and symbolic forms of semiotization of the concept family in the English and Russian linguistic communities on the material of John Galsworthy's novel "The Forsyte Saga" and translation of its microtexts into Russian. The investigation is aimed to found out the concept perception degree of the English and Russian speakers' linguistic consciousness and to define the typical and nationally-specific semiotic conceptual features of the noted ethnics.

\section{References}

1. Алефиренко Н.Ф. Спорные проблемы семантики: Монография. Москва : Гнозис, 2005. 326 с.

2. Арнольд И.В. Лексикология современного английского языка. Москва : Высш. шк., 1986. 295 с.

3. Бабенко Л.Г. Лингвистический анализ художественного текста. Теория и практика. Москва : Флинта : Наука, 2005. 496 с. 
4. Байбурин А.К. Об этнографическом изучении этикета. Этикет у народов Передней Азии. Москва : Наука (Глав. ред. вост. лит.), 1988. С. 12-37.

5. Голубовська I.О. Етнічні особливості мовних картин світу : Монографія. Київ : Логос, 2004. 284 с.

6. Зубкова Л.Г. Лингвистические учения конца XVIII - начала XX в.: Развитие общей теории языка в системных концепциях. Монография. Москва : Изд-во УДН, 1989. 212 с.

7. Зорівчак Р.П. Фразеологічна одиниця як перекладознавча категорія (На матеріалі перекладів творів української літератури англійською мовою). Львів : Вид-во при Львів. ун-ті, 1983. 175 с.

8. Колесов В.В. О логике логоса в сфере ментальности. Мир русского слова. 2000. № 2. С. 56.

9. Кухаренко В.А. Интерпретация текста. Москва : Просвещение, 1988. 192 с.

10.Лексикология английского языка / Р.З. Гинзбург, С.С. Хидекель, Г.Ю. Князева, А.А. Санкин. М. : Высш. шк., 1979. $269 \mathrm{c.}$

11. Маслова В.А. Лингвокультурология. Москва : Академия, 2001. 208 c.

12. Матезиус В. Язык и стиль. Пражский лингвистический кружок. Москва : Прогресс, 1967. С. 444-523.

13. Мостовий М.I. Лексикологія англійської мови. Харків : Основа, 1993. 256 с.

14.Снитко Е.С. Этнические культуры в зеркале язика. Мова i культура: Наукове видання. Київ : Вид. Дім Дмитра Бураго, 2003. T. IV. Вип. 6: Міжкультурна комунікачія. Теорія $i$ практика перекладу. С. 5-10.

15.Тер-Минасова С.Г. Язык и межкультурная коммуникация. Москва : Слово, 2000. 624 с.

16.Шрейдер Ю.А. Ритуальное поведение и формы косвенного целеполагания. Психологические механизмы регуляции социильного поведения. Москва : Наука, 1979. С. 103-127.

17. Языкознание. Большой энциклопедический словарь. Москва : Больш. Рос. энцикл., 2000. 688 с.

18. Bedarida Francois A social history of England. London and New York, 1994. 384 p.

19. Cannadine David History in our time. Penguin Books, 2000. 313 p.

20. Durand G. Les structures anthropologiques de l'imaginaire. Paris : Dunod, 1997. 536 p. 
21.Gorer J. Exploring English Character. New York, Criterion Books, 1955. $328 \mathrm{p}$.

22. Himmelfarb, Gertrude The De-Moralisation of Society From Victorian Virtues to Modern Values. N.Y. : Alfred A. Knopf, 1985. $287 \mathrm{p}$.

23.Cambridge International Dictionary of English. Cambridge : Cambridge University Press, 1995. 1773 p.

24. The New Oxford Dictionary of English. Oxford: Oxford University Press, 1998. 2152 p.

25. Galsworthy J. The Forsyte Saga. Book One. The Man of Property. Moscow : Progress, 1974. 383 p.

26. Galsworthy J. The Forsyte Saga. Book Two. In Chancery. Moscow : Progress, 1975. $385 \mathrm{p}$.

27. Galsworthy J. The Forsyte Saga. Book Three. To Let. Moscow : Progress, 1975. $256 \mathrm{p}$.

Information about the author: Soroka Tetiana Vyacheslavivna,

Candidate of Philological Sciences, Associate Professor at the Department of the English Philology Ismail State University of Humanities 12, Repin str., Izmail, Odesa region, 68600, Ukraine 